\title{
Web-based knowledge management model for managing and sharing green knowledge of software development in community of practice
}

\begin{abstract}
Emerging awareness of sustainability matters urge the people go for green computing as solution to the environmental problems. There were a lot of previous researches studied about hardware solution, and only few papers that focused on green software area. However, there is lacking of research that discusses about how to implement knowledge management method to manage the green knowledge of software development. As we know that software development is an important role in supporting the IT community, hence the unmanaged green knowledge of software development will lead to the problem of unable to meet both the environmental and business demands to the community. Therefore, this research will focus on proposing a model that applies web-based knowledge management system to manage and share the green knowledge of software development among the members of community of practice in software development environment.
\end{abstract}

Keyword: Community of practice; Green software development; Green technology; Sustainability; Web-based knowledge management 